research capabilities have been spent sensibly. No detailed information has been collated on how the money has been spent, and officials say that the long-term nature of such investment makes it too early to judge whether it has been a success.

But there are signs that the technology gap has been slowly narrowing. National expenditure on research and numbers of research workers per capita in the four cohesion countries have grown since 1989. So too has scientists' publication output.

Tom Higgins is director of the Dublinbased consultancy Circa, which has analysed the use of the 1988-93 structural funds for research in Portugal, Ireland and Greece. He says this improvement "is likely due to structural funds, simply because of the large amounts of money involved".

But Higgins says that the commission "should not assume that such parameters indicate that the primary goal of cohesion policy - increased industrial competitiveness - has been achieved". He says there has been neglect of the 'demand' side of research effort - local industrial needs - while too much has been spent on 'supply', the building of infrastructure. The commission concedes this point.

Most structural funds relating to research have been spent on infrastructure. For example, 50 new research institutes have been built with structural funds in Portugal and 100 have been refurbished.

\section{Building to a critical mass}

Anecdotal evidence suggests that new research institutes in scientifically remote regions are most likely to be successful if they are backed by experienced research institutes in richer areas, or can quickly build up critical mass of highly trained researchers (see panel, right).

But spending large sums on research infrastructure is not as easy as it sounds. Structural funds are withdrawn if not spent in the year allocated, so it is easier to attach them to projects already planned.

The creation of a marine research institute at the University of Galway in western Ireland in 1993 is one example of a planned project that was awaiting only financing. New ideas for projects are harder to get started fast enough. The Stride programme, originally intended to run for only four years, has been extended by three years because of the difficulties some countries have in rapidly using large amounts of funding.

Italy has spent only 70 per cent of its Stride money and is unlikely to be able to spend the rest before the programme ends in December. It has had the biggest problems, partly because its political instability has upset the legal structure needed to administer the money.

A desire to make the most of an opportunity that may soon end partly explains
Italy's interest in proposing itself as a possible location for ITER, the next-generation experimental fusion reactor. Structural funds would pay for the infrastructure (see Nature 384, 507; 1996).

A further indicator of the success of cohesion policies is the increased participation of the four cohesion countries in the Framework research programme.

Between 1987 and 1990, half the Framework funds went to scientists working in 12 so-called 'islands of innovation' which stretch between London and Milan and include Amsterdam/Rotterdam, Ile de France and Munich. This is despite the fact that what is nicknamed Archipelago Europe accounts for only 28 per cent of the EU population. In the same period, only 10.5 per cent of funds went to the four cohesion countries. Between 1991 and 1994 the share of the 'archipelago' had fallen to 45 per cent, while that of the cohesion four had risen to more than 12 per cent.

The commission's directorate for cohesion believes Framework is still élitist. But any pressure to make the fifth Framework programme more favourable to cohesion regions is unlikely to win through.

\title{
Molecular biology reaps the benefits
}

[MUNICH] Those seeking evidence of the success of structural funding need look no further than the Greek Institute of Molecular Biology and Biotechnology (MBB)

Established in 1984 in Heraklion on the island of Crete, the institute has become a flagship of

European research.

The institute was built and equipped almost entirely with structural funds, which have also supported some of its projects in the 1990s. It has a staff of 150 , a graduate school programme and a strong publication record.

When the Greek government proposed the use of European Union (EU) money to establish a series of research institutes outside Athens in the early 1980s, Fotis Kafatos, then professor of molecular biology at Harvard University in the United States, returned to his native Greece to become

IMBB's first director.

By 1990 the institute was participating in 12 projects of the European Commission's Framework research programme, where scientists from different countries must join forces to compete for funds.

\section{By the end of 1992 ,} scientists at the institute were running 30 programmes and they now participate in 45 .

The institute was the first to demonstrate transfer of genes into an insect other than the fruitfly Drosophila. The recipient was the Mediterranean fruitfly Ceratitis capitata, a species of agricultural importance. Structural funds financed the whole project.

One of the secrets of the institute's success, according to Kafatos, who left in 1993 to become director of the Heidelberg-based European Molecular Biology Laboratory, was the opportunity given by

\section{IMAGE UNAVAILABLE FOR COPYRIGHT REASONS}

Thireos: regrets lack of interest in research from local industry.

the generous structural funds "to bring in large numbers of highly qualified, foreigntrained scientists and give them the appropriate conditions in which to work".

It was also important, he says, that the institute was not built in isolation but as part of a complex of research institutes belonging to Greece's Foundation for Research and Technology.

The IMBB's current director, George Thireos, is proud that after "wisely spending" structural funds, the institute is now able to survive on competitive grants. But he regrets that plans to spin off the institute's enterprises - which last year brought in EQU112,000 - have been hindered by local industry's lack of interest in research.

Italy's Mario Negri Sud research institute at Santa Mario Imbaro was one of 14 institutes set up in the 1980 s in Italy's poor south, where the government wanted to stimulate the economy. Even now, only 7 per cent of Italy's national expenditure on research and development is invested in the area.

The institute is the only one of the 14 that continues to do research, mainly in cardiovascular biology. Its success is largely due to the expertise of the Mario Negri Institute for Pharmacological Research in Milan, which helped to set it up, and continues to work with it in close collaboration. The other 13 institutes offer only scientific services.

Despite the bold programme in the 1980 s to stimulate development in the south, the institute has been left by the Italian government to sink or swim. Silvio Garattini, director of the Milan institute, regrets the lack of government interest in helping to sustain theEU structural fund investment.

Mario Negri Sud's director, Giovanni de Gaetano, a southerner who trained at the Milan Mario Negri Institute, says structural funds have been well spent. "it has also been comparatively cheap", he says. "The $\mathrm{L} 40$ billion (US\$26 million) invested [from structural funds] is equivalent to one or two kilometres of motonway."

AA 